\title{
Influence of Corporate Governance on the Performance of MFIs Through Trust and Participation:
}

\author{
Studies at the Community Base Saving Loan Organisation (CBSLO) at South Kalimantan
}

\author{
Moh. Heru Budihantho* \\ Student of Doctoral Program of \\ Business Administration, \\ Brawijaya University \\ Malang, Indonesia \\ *moh.herubudihantho@gmail.com
}

\author{
Suhadak, Hamidah Nayati Utami \\ Department of Business Administration, \\ Brawijaya University \\ Malang, Indonesia \\ suhadak_fia@yahoo.co.id
}

\author{
Solimun \\ Department of Statistics, \\ Brawijaya University \\ Malang, Indonesia \\ solimuns@gmail.com
}

\begin{abstract}
This research examines the impact of corporate governance on trust, performance, and participation. the effect of trust on participation and performance. The influence of trust on participation and performance. This research is explanatory with approach quantitative. The data were collected from 12 CBSLO results of the Community Empowerment Rural Development project. Data analysis used WarpPLS. Study finding showed that corporate governance has a significant positive impact to trust, corporate governance has a significant negative impact on MFI performance, corporate governance has a significant positive impact on participation, and trust has a significant positive impact on participation and trust has no significant impact on MFI performance, while participation has a significant positive impact on performance. Indirectly, corporate governance has a significant positive impact on performance through trust and participation.
\end{abstract}

Keywords-corporate governance, trust, participate, performance, non-subsidi Mfi

\section{INTRODUCTION}

The community empowerment for Rural Development (CERD) program, is one of the programs implemented by the Indonesian government in order to reduce poverty due to the economic crisis in 1998. One of its activities is to develop a rural financial institution called CBSLO (Community Base Saving Loan Organization) which is developed with the principles of self-help and mutual help by mobilizing community self-sufficiency. This is different from other empowerment programs that use grants, subsidies, or revolving funds.

Many studies empirically conclude that microfinance has the potential to reduce poverty [1-3]. Mfi services have an impact on increasing the ability of poor individuals to improve income, increasing consumption levels, health, and building assets [4].

MFIs that serve the poor and disadvantaged are relatively more at risk, namely the risk of excess debt, credit repayment, and the quality of management and governance [5]. Besides fraud, low participation of members, lack of knowledge and skills management, weak internal control system, and the low level of accountability is found as the main challenges facing $\mathrm{d}$ nature obeys the practice of corporate governance [6].

Sustainability MFI because it implements effective business practices. However, unsuccessful MFIs, due to poor business practices and mismanagement [7]. MFIs with revolving fund sources perform poorly due to: (i) Poor financial management, (ii) Perceptions of credit as a grant, (iii) corruption and (iv) lack of experience [8]. Based on the above study results, MFIs face problems of operational sustainability, low trust and participation and poor corporate governance practices.

Corporate governance is needed to create trust, corporate governance structures support trust in internal and external financial sources that contribute to long-term success [9]. Corporate governance makes companies honest and without problems. Dishonest and unethical transactions can cause shareholders to run away out of fear, distrust, and disgust [10]. 
Trust is the cornerstone of many facets of microfinance activities and is a determinant of microfinance 's performance. Trusts coordinate relationships between customers and loan officers within borrower groups and between customers and institutions [11]. Trust can affect governance structures, negotiation costs, risk perceptions in strategic alliances, and business unit performance [12]. Trust is the basis for social exchange. Social exchange theory [13]. States that the relationship between members and organizations is a social reciprocal relationship when members feel the benefit of the organization, members feel obliged to repay good treatment through their existing obligations to participate in the MFI.

The research carried so far is research on the effects of corporate governance on Mfi performance in urban areas. Meanwhile, research related to the influence of corporate governance on trust and participation. As well as the effect of trust on performance there is very little literature available. Several studies on the influence of corporate governance, trust, participation, and performance are partial, such as; the effect of corporate governance on performance [14-17]. So far, there are not many studies on the effect of corporate governance on trust [18], the effect of trust on participation [19,20], the effect of trust on performance $[12,21]$, and the effect of participation approaching performance [22]

Based on the research gap above and the phenomena faced by MFIs in community empowerment programs, so that MFIs can sustainably provide services for the poor and microbusinesses, this study constructs a model framework for the influence of corporate governance on MFI performance through trust and participation as a novelty of research.

This study will be carried out in rural areas of South Kalimantan, considering the presence of CBSLO from the CERD Program in South Kalimantan. In addition to the fact that CBSLO has shown the best results in terms of number of participants, assets, investments, and loan accumulation in the six provinces where the CERD project exists, it is still sustainable even though the project has been completed.

\section{LITERATURE REVIEW AND HYPOTHESIS}

\section{A. Corporate Governance and the Trust}

Corporate governance is needed to create trust [9]. Good corporate governance will facilitate access to sources of capital [23], A corporate governance structure underpins the trust in internal and external financial sources that contribute to longterm success [9], Yousaf, et al. show that there is an effect of good governance on citizen trust [18]. Consistency of behavior, the integrity of behavior, participatory decision making, communication, and demonstrative attention are behaviors that demonstrate trust [24]. However, the most prominent characteristics of trust are integrity, virtue, and competence [25-27], Having business competence, being reliable, being thorough in their transactions, and having good intentions are the basis of trust in cooperatives. Evidence of belief is shown voluntarily joining, and voluntarily supporting and applying for a loan, based on this a hypothesis can be drawn up as follows: trus

H1. Corporate governance significant positive impact on

\section{B. Corporate Governance and the Performance of MFIs}

The quality of MFI governance is determined by the competence board, board activities, and types of ownership [28]. Corporate governance has an effect on company performance [29]. The number of management and audit committees has a positive relationship with company performance but meeting frequency has a negative relationship. female leadership has a significant relationship with a larger board, the company is still in its early stages, non-profit legal status, and more female clients [14].

Corporate governance affects the performance (economic and social) and productivity of MFIs in Pakistan. Gohar and Batool [16] and Moenga [30] found that independent board has the greatest impact on MFI financial performance, followed by board diversity and CEO duality. Meanwhile, the number of management negatively affects the financial performance of MFI. This basic bag can be hypothesized as follows;

$\mathrm{H}$ 2. Corporate governance has a significant positive impact on MFI performance

\section{Corporate Governance and Participation}

MFI board encourages the mental and emotional involvement of members to contribute and be responsible for achieving the goals of the MFI [31]. Through regular communication and encouraging involvement in decisionmaking processes that help maintain the direction of the MFI and ensure successful performance [32]. Management must ensure the openness of the MFI's operations and improve members' participatory skills [33]. Increased participation occurs when members are involved in the decision-making process and the democratic control of organizational management. There is a significant independent relationship (non-material motivation and material motivation, perception, service quality, facilities and infrastructure, managerial management, education, and training) with member participation [34]. On this basis, the following hypotheses can be formulated:

H3. corporate governance has a significant positive impact on participation

\section{The Trust and Participation}

Trust is used to explain the behavior of individuals to the organization in social exchange relationships [35,36]. Social exchange between two parties includes mutual obligations that are long term, unlike formal contracts in economic exchange which ensure that both parties fulfill their short-term obligations [13]. Social exchange theory is mainly based on [37], norm of reciprocity, according to this theory, when 
mutually beneficial actions occur between members and cooperatives. The members are confident that the cooperative will fulfill its obligations and act reciprocally and be kind to the cooperative. thus impacting on member participation.

Trust is related to the participatory behavior of members in cooperative governance [38]. Trust in cooperatives makes members committed to the organization [39], loyal [40], and active in cooperative governance [19]. Trust has a central role in participatory processes [20]. On this basis, the following hypotheses can be arranged:

H4 The trust has a significant positive impact on participation

\section{E. Trust and MFI Performance}

Borrowers or lenders are vulnerable to the MFI. Borrowers are vulnerable to fraud by loan officers and MFIs, people who are vulnerable to loan repayments [11]. Trust in institutions includes the assumption that it is difficult to trust institutions, comply with laws and regulations, and represent the public interest. This implies the conviction that the organization is professional, fulfills its duties and behaves responsibly [41]. If the prospective consumer does not trust the institution, then as a financial service provider, they will not contact the MFI. Customer transactions will increase the impact of trust on the performance of MFIs [21]. Increase transactions through rising the volume of deposits and loans. Increased profitabilityenhancing operations [42]. On this basis, the following hypothesis is compiled:

H5. Trust has a significant positive impact on MFI performance

\section{F. Participation and MFI Performance}

Participation is the most important factor in supporting the success or development of an organization. all program to be implemented by the Management needs to gain the support of all the elements that exist within the organization [43], Meanwhile, Redjeki et al. [22], research shows that member participation has a significant positive effect on business performance. Attendance at the annual meeting has a positive effect on capital participation, and encourages the realization of common goals, and has an impact on the performance of MFIs [44]. Rajesh [45] stated that the participation of members in cooperation activities in quantity and quality can increase the perception and control of cooperative performance. Hammad et al. [32] shows that member participation is critical to cooperative success in the long term. On this basis, the following hypothesis is compiled:

H 6. Participation has a significant positive impact on the performance of MFIs

Based on the description above, the hypothesis of the influence between variables which is formulated in 6 hypotheses can be seen in the hypothetical framework Figure 1

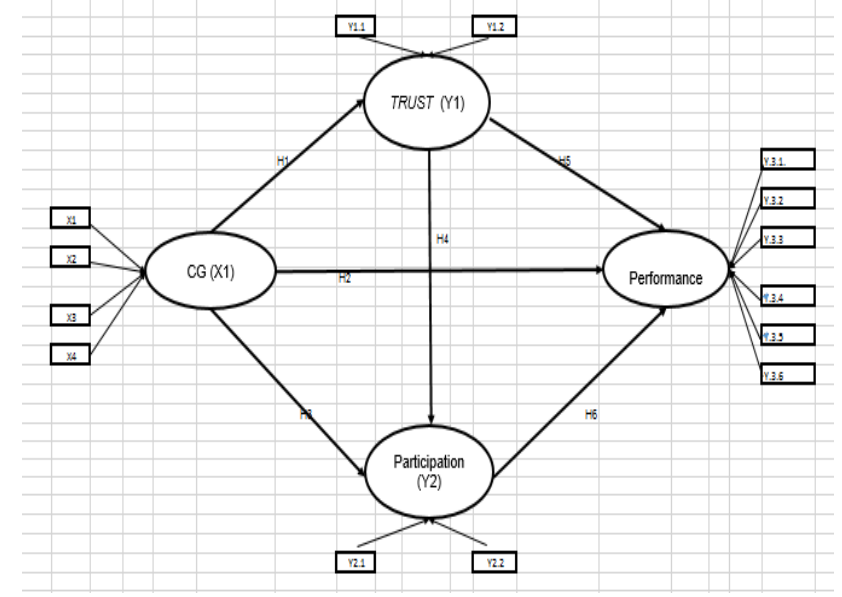

Fig. 1. The hypothetical framework.

\section{RESEARCH METHODS}

\section{A. Data collection and Sample}

Population in research is the entire MFi of the Community empowerment Rural Development program in the Southern Kalimantan Province with the total of 20, with the criteria of:

- Consecutively, from 2014 to 2018 doing the annual meeting.

- The MFi reported the statement of financial position and the report of the income statement consecutively from 2014 to 2018.

- The age of the MFi is above 10 years.

Based on the three criteria, the ones fulfilling the requirement of population for the research are 12 MFis. The sampling technique used is the saturated sampling for the ones fulfilling the criteria for the research sampling. The research uses the data panel that is a mixture between the data of time series and the cross section. The data panel consists of $12 \mathrm{MFis}$ $\mathrm{x} 5$ years, so that the data is in the total of 60 . 


\section{B. Measurement}

TABLE I. VARIABLES, INDICATORS, MEASUREMENT AND SOURCES

\begin{tabular}{|c|c|c|c|}
\hline Variable & Indicator & Measurement & Source \\
\hline \multirow{4}{*}{$\begin{array}{l}\text { (X1) } \\
\text { Corporate } \\
\text { Governan } \\
\text { ce }\end{array}$} & (X1) Board Size & $\begin{array}{l}\text { Number of board } \\
\text { members }\end{array}$ & {$[17]$} \\
\hline & $\begin{array}{l}\text { (X2) Diversity } \\
\text { Board }\end{array}$ & $\begin{array}{l}\text { Percentage of total } \\
\text { female board members }\end{array}$ & [17] \\
\hline & $\begin{array}{l}\text { (X3) } \\
\text { Board Meeting }\end{array}$ & $\begin{array}{l}\text { The frequency of board } \\
\text { meetings in a year }\end{array}$ & [46] \\
\hline & $\begin{array}{l}\text { (X4) Independent } \\
\text { Board }\end{array}$ & $\begin{array}{l}\text { Percentage of number of } \\
\text { board members outside } \\
\text { of users }\end{array}$ & {$[46]$} \\
\hline \multirow[t]{2}{*}{$\begin{array}{l}\text { (Y1) } \\
\text { Trust }\end{array}$} & $\begin{array}{l}\text { (Y1.1) Growth in } \\
\text { the number of } \\
\text { users }\end{array}$ & $\begin{array}{l}\text { The percentage increase } \\
\text { in the number of users in } \\
\text { a year }\end{array}$ & [47] \\
\hline & $\begin{array}{l}\left(\begin{array}{ll}Y & 1.2\end{array}\right) \text { Loan } \\
\text { growth }\end{array}$ & $\begin{array}{l}\text { The percentage increase } \\
\text { in the number of loans } \\
\text { granted in a year }\end{array}$ & [47] \\
\hline \multirow[t]{2}{*}{$\begin{array}{l}\text { (Y2). } \\
\text { Partici } \\
\text { pation }\end{array}$} & $\begin{array}{l}(\mathrm{Y} 2.1 .) \% \text { Of users } \\
\text { present in annual } \\
\text { meeting }\end{array}$ & $\begin{array}{l}\text { Percentage of MFI users } \\
\text { who attend annual } \\
\text { meeting }\end{array}$ & [48], \\
\hline & $\begin{array}{lr}\mathrm{Y} 2.2 .) \% & \text { Users } \\
\text { who } & \text { are } \\
\text { administrators }\end{array}$ & $\begin{array}{l}\text { Percentage of LKM } \\
\text { users in the Board }\end{array}$ & [48] \\
\hline \multirow[t]{6}{*}{$\begin{array}{l}(\mathrm{Y} 3) \\
\text { perfor } \\
\text { mance }\end{array}$} & (Y3.1) ROA & $\begin{array}{l}\text { Return on assets is net } \\
\text { income divided by total } \\
\text { assets }\end{array}$ & [49] \\
\hline & (Y3.2) OSS & $\begin{array}{ll}\text { Operational self- } \\
\text { sufficiency is total } \\
\text { income divided by } \\
\text { expenses }\end{array}$ & [49] \\
\hline & $\begin{array}{l}\text { (Y3.3) } \\
\text { FSS }\end{array}$ & $\begin{array}{l}\text { Financial self- } \\
\text { sufficiency is the ratio } \\
\text { between income to total } \\
\text { expenditure }+5 \% \text { of the } \\
\text { total loan }\end{array}$ & [49] \\
\hline & $\begin{array}{l}\text { (Y3 4) Number of } \\
\text { active borrowers }\end{array}$ & $\begin{array}{l}\begin{array}{l}\text { Number of active } \\
\text { borrowers }\end{array} \\
\end{array}$ & {$[15]$} \\
\hline & $\begin{array}{l}\text { (Y3. 5) Average } \\
\text { Loan }\end{array}$ & $\begin{array}{l}\text { Total funds borrowed / } \\
\text { total borrowers }\end{array}$ & [15] \\
\hline & $\begin{array}{lr}(\text { Y3.6 ) } & \text { Number } \\
\text { of } & \text { female } \\
\text { borrowers }\end{array}$ & $\begin{array}{l}\text { The ratio of female } \\
\text { borrowers to the total } \\
\text { number of borrowers }\end{array}$ & [15] \\
\hline
\end{tabular}

Source: Previous Research (2020)

\section{Data Analysis}

The analysis data used inferential statistical analysis is used to test the effect of the variables in this research. The researcher used the WarpPLS statistical tool.

\section{RESEARCH FINDINGS}

\section{A. Hypothesis Test}

Based on the results of hypothesis testing, by comparing the $p$ value with alpha $5 \%$. If $p$ value $\leq 0.05$, then the hypothesis is accepted and if the $\mathrm{p}$ value is $>0.05$ then the hypothesis is rejected. Then the resulting hypothesis test results are as follows Table 2:
TABLE II. HYPOTHESIS TESTING RESULTS

\begin{tabular}{|c|c|c|c|c|}
\hline Hypo thesis & $\begin{array}{c}\text { Influence } \\
\text { between } \\
\text { variables. }\end{array}$ & $\begin{array}{c}\text { path } \\
\text { coefficient }\end{array}$ & P Value & $\begin{array}{l}\text { Sign } \\
\text { level }\end{array}$ \\
\hline 1 & $\begin{array}{l}\text { Corporate } \\
\text { Governanc } \\
e \text { towards } \\
\text { trust }\end{array}$ & 0.210 & $0.042 *$ & Significant \\
\hline 2 & $\begin{array}{l}\text { Corporate } \\
\text { Governanc } \\
e \quad \text { on } \\
\text { performan } \\
\text { ce }\end{array}$ & 0.444 & $<0.001 *$ & Significant \\
\hline 3 & $\begin{array}{l}\text { Corporate } \\
\text { Governanc } \\
e \text { towards } \\
\text { participati } \\
\text { on }\end{array}$ & -0.488 & $<0.001 *$ & Significant \\
\hline 4 & $\begin{array}{l}\text { Trust in } \\
\text { participati } \\
\text { on }\end{array}$ & 0.232 & $0.027 *$ & Significant \\
\hline 5 & $\begin{array}{l}\text { Trust in } \\
\text { Performan } \\
\text { ce }\end{array}$ & -0.056 & $.0,326$ & $\begin{array}{l}\text { not } \\
\text { Significant }\end{array}$ \\
\hline 6 & $\begin{array}{l}\text { Participati } \\
\text { on in } \\
\text { Performan } \\
\text { ce }\end{array}$ & 0.212 & $0.040 *$ & Significant \\
\hline
\end{tabular}

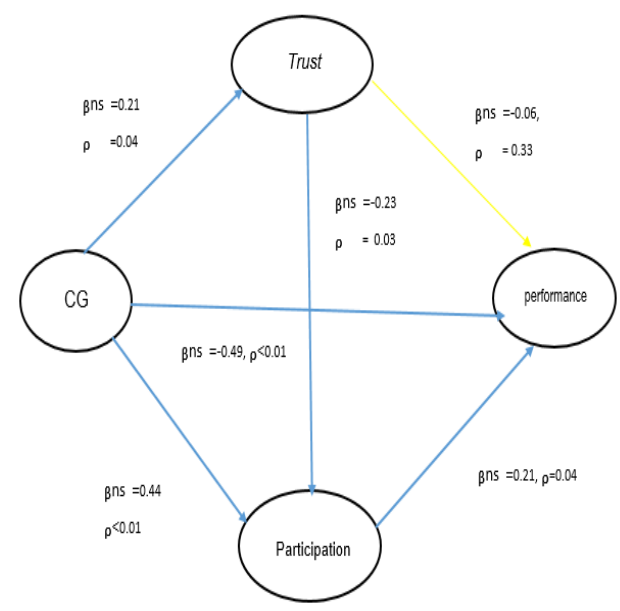

Fig. 2. Final structural model.

\section{DisCUSSION OF RESUlTS}

The results showed that corporate governance had a significant positive impact on trust. This is because the source of MFIs capital comes from self-help, so that management is working hard to convince the community to become members and saving. MFIs provide information regularly through the financial statements and progress MFIs and are managed in a transparent, accountable, and trustworthy. This principle is being developed to improve to trust and eliminate the bad experiences of people against this kind of institution. 
The finding supporting Signaling Theory [50], if the good corporate governance is a good signal for the members, so that members confidence in the management of MFIs. The results also support the research Yousaf et al. [18], Hansen et al. [27].

The results of the study showed that corporate governance significantly negative impact on performance. Some of the reasons that lead to a significant negative corporate governance effect on MFI performance are: First because being a Mfi board is a side job and dedication. Second, most of the MFI board are women $(67.62 \%)$.

The results of this study support Thrikawala et al. [17] show that more female directors have a significant negative effect on performance. This suggests that an MFI has better financial performance if it has fewer female representatives on the board. The same thing is also with research by Ferial et al. [52], shows that good corporate governance has a significant negative effect on financial performance. The results of the study also support the research of Gohar and Batool [16], which states that managers are more inversely proportional to economic performance and the duality of chairs and CEOs is a negative contributor to performance, outreach, and productivity.

The result of the indirect effect shows that corporate governance has a significant positive impact through trust and participation. This suggests that participation plays an important role in the influence of corporate governance on performance in MFIs that rely on funds from members

Corporate governance has a significant positive impact on participation. The results of this study indicate that management can encourage participation in the decisionmaking process that can maintain direction and ensure successful performance. The results of this study support the signaling theory which states that good corporate governance is a signal for members to participate in Mfi. The results of the study are in line with the research of Ernita and Al-Rozi [34], Davis and Newstrom [31].

The results show that trust has a significant positive impact on participation. because of both the user and the owner of $\mathrm{MFi}$, a sense of belonging to the institution, and actively participating in the annual meeting. The results of this study support [19], who show affective commitment mediates the relationship between trust and member participation in cooperative governance. The results of the research support the social exchange theory [13] that trust affects participation.

Trust has no significant impact on performance. trust does not have a significant effect on performance due to limited transactions, due to limited funds raised, because, in nonsubsidized MFIs, the source of funds must be mobilized from member savings. So, growth in the number of funds lent is also lower. The results of this study do not support [21], which shows that customer trust, have a positive and significant effect on customer transactions in cooperatives.

Participation a significant positive impact on performance. This is because $70 \%$ of members attend the annual meeting and are involved in the decision-making process. Higher participation will reduce agency costs, because more members monitor the performance of the board. The results of this study are in line with Agency theory [53], which states that corporate governance improves performance by solving agency problems through monitoring, controlling and examining the reporting process. member participation is very important for the success of cooperatives in the long term [32].

\section{CONCLUSION}

Corporate governance has a significant positive impact on trust, participation and significant negative effect on performance. Trust has a significant positive impact on participation and does not have a significant effect on performance. Participation has a significant positive effect on performance and finally, indirectly, corporate governance and trust has a significant positive effect on performance through participation.

The results showed that participation is the key to successful performance. Contribution to MFIs, If you want to sustainably provide services for the poor and micro enterprises for the poor to increase income, increase consumption levels, health, and build assets. So it is necessary to improve good corporate governance so that the trust and participation of members increases.

The limitation of this research is that this research is conducted with a quantitative approach so that to get a more complete picture, it is necessary to qualitatively examine the variables of corporate governance, trust, and level of participation.

\section{REFERENCES}

[1] B. Armendariz de Aghion and J. Morduch, "The Economics of Microfinance", The Mit Press Cambridge, Massachusetts London, England, 2005.

[2] S. Bakhtiari, "Microfinance And Poverty Reduction: Some International Evidence," International Business \& Economics Research Journal (IBER), vol. 5, no. 12, 2011

[3] S. Johnson and B. Rogaly, Microfinance and poverty reduction", Oxfam Publication, 1997.

[4] B. Appah, S.M. John, and W. Soreh, "Analysis of Microfianance and Poverty Reduction in Bayelsa State," Arabian Journal of Business and Management Review, vol. 1, no. 7, pp. 38-52, 2012.

[5] Center for the Study of Financial Innovation (CSFI), MFi Banana Skins. New York: The CSFI Survey of MFi Risk, 2014.

[6] M. Patrick, Legal Form, Performance and Risk in the MFi Industry, Master Theses Faculty of Law, Economics and Governance. Utrecht University, 2015.

[7] N.L. Zuru, Mohd Khairuddin Hashim and Darwina Arshad, "Business Practices for Sustaining Performance of MFi Institutions: A Literature Review," International Journal of Management Research \& Review, Vol 6, issue 8, article No3 pp.1000-1011, 2016.

[8] Holloh, Detlev, Review Of The PPK Microcredit Approach: World Bank Group, Washington DC, 2001

[9] J. Simpson and J. Taylor, Corporate governance, ethics, and CSR . London, UK: Kogan Page, 2013. 
[10] R. Vishwakarma, "Effect of Governance on the Performance of Selected Indian MFi Institutions: An Empirical Study," European Journal of Business and Management, Vol. 7, No. 4, 2015.

[11] M.J. Epstein and K. Yuthas, " The Critical Role of Trust in MFi Success: Identifying and Problems and Solution," Journal of Developmental Entrepreneurship, Vol. 16, No. 4, pp. 477-497, 2011.

[12] Morrow Jr..J.L., Mark H. Hansen and Allison W.Pearson, "The Cognitive and Effective Antecedents of General Trust Within Cooperative Organization,” Journal of Managerial Issues, vol. 16, no. 1, pp. 48-64, 2004

[13] P. Blau, Exchange and Power in Social Life. New York: Wiley, 1964

[14] R.Ø. Strøm, B. D’Espallier, and R. Mersland, "Female Leadership, Performance, and Government in MFi Institutions," Journal of Banking \& Finance, vol. 42, (2014), pp. 60-75, 2014

[15] Bakker, A. Jaap Schaveling and André Nijhof, "Governance and MFi Institutions," Corporate Governance, Vol. 14 Iss 5 pp. 637 - 652, 2014

[16] R. Gohar and A. Batool, "Effect of Corporate Governance on Performance of MFi Institutions: A case from Pakistan," Emerging Market Finance and Trade, 51:sup6,S94-S106, 2015.

[17] S. Thrikawala, S. Locke and K. Reddy, "Board Structure -Performance Relationship in MFi Institution (Mfi) in An Emerging Economy," Corporate Governance: The International Journal of Business in Society, Vol. 16, Issue, 5, pp. 815-830, 2016.

[18] M. Yousaf, F. Ihsan, and A. Ellahi, "Exploring The Impact of Good Governance on Citizens' Trust in Pakistan," Government Information Quarterly, vol. 33, pp. 200-209, 2016

[19] V. Barraud-Didier, M. Henninger, and A.E. Akremi, "The Relationship Between Members' Trust and Participation in The Governance of Cooperatives: The Role of Organizational Commitment," International Food and Agribusiness Management Review, vol. 15, no. 1, pp. 1-24, 2012.

[20] J. Birchall and R. Simmons, "What Motivates Members to Participate in Cooperatives and Mutual Businesses?," Annuals of Public and Cooperative Economics, vol. 75, no. 3, pp. 465-495, 2004a.

[21] Murti and Santika, "Pengaruh Kepercayaan Nasabah, Bauran Produk dan Bauran Lokasi Terhadap Transaksi Nasabah,” E-Jurnal Manajemen Unud, Vol. 5, No.1, pp. 734-761, 2016

[22] A.M. Redjeki, B. Purwoko, and A.M. Sumarlin, "Analisis Strategi Fungsional Tentang Pengaruh Komitmen Dan Partisipasi Anggota Terhadap Kinerja Koperasi Pemerintah (Studi Kasus Koperasi Pegawai Kementerian Sosial RI)," Jurnal online Pascasarjana Universitas Pancasila, 2016.

[23] IFC, The Indonesia Corporate Governance Manual, First Edition, IFC and OJK, 2014

[24] D.K. Dirks, Three Fundamental Questions Regarding Trust in Leaders. In Handbook of Trust Research, ed. Reinhard Bachmann and Akbar Zaheer, 15-28. Cheltenham, UK: Edward Elgar Publishing Limited, 2006.

[25] R.C. Mayer, J.H. Davis, and F.D. Schoorman, "An Integrative Model of Organizational Trust," Academy of Management Review, vol. 20, no. 3 , pp. 709-734, 1995.

[26] J.E. Post, L.E. Preston, and S. Sachs, Redefining The Corporation: Stakeholder Management and Organizational Wealth. Stanford, CA: Stanford University Press, 2002.

[27] Hansen, Mark H. and J.L. Morrow Jr, "Trust and The Decision to Outsource: Affective Responses and Cognitive Processes," International Food and Agribusiness Management Review, vol. 6, no. 3, pp. 1-30, 2003

[28] T.T. Hubert, Determinants of The Governance Quality of Microfinance Institutions. The Quarterly Review of Economics and Finance, 2015.

[29] S. Danoshana and T. Ravivathani, "The Impact of The Corporate Governance on Firm Performance: A Study on Financial Institutions in Sri Lanka," Merit Research Journals, pp. 118-123, 2013.

[30] G.O. Moenga, The Effect of Corporate Governance on The Financial Performance of MFi Institutions in Kenya. A Research Project The
Award of The Degree of Master of Science of The University of Nairobi, 2013

[31] K. Davis, and J. Newstrom, Human Behavior at Work. Organization Behavior 8th Edition. Singapore: Mc. Graw-Hill. International, 1989

[32] Hammad, A., Mahazril'Aini Y, Hussin Abdullah, Siti Hajar ABA, "Factors Affecting Performance of Cooperatives in Malaysia," International Journal of Productivity and Performance Management Vol. 65 No. 5, 2016 pp. 641-671, 2016.

[33] R. Shaffer, S. Deller, and D. Marcouiller, "Rethinking Community Economic Development," Economic Development Quarterly, vol. 20, no. 1, pp. 59-74, 2006

[34] Ernita, firmansyah and A. Al-Rozi, "Factors Affecting The Members Participation On Cooperative In North Sumatera," International Journal Of Scientific \& Technology Research ,Volume 3, ISSUE 10, October, 2014

[35] Ferrin, Donald L. and Kurt T. Dirks, "The Use of Rewards to Increase and Decrease Trust: Mediating Processes and Differential Effects," Organization Science, vol. 14, no. 1, pp. 18-31, 2003.

[36] R.M. Kramer, Trust As Situated Cognition: An Ecological Perspective. In Handbook of Trust Research, ed. Reinhard Bachmann and Akbar Zaheer, 68-84. Cheltenham, UK: Edward Elgar Publishing Limited, 2006

[37] A.W. Gouldner, "The Norm of Reciprocity: A Preliminary Statement," American Sociological Review, 1960.

[38] P. Osterberg and J. Nilsson, "Members' Perception of Their Participation in The Governance of Cooperatives: The Key to Trust and Commitment in The Agricultural Cooperatives'," Agribusiness, vol. 25, no. 2, pp. 181-197, 2009.

[39] S.O. Borgen, "Identification as A Trust-Generating Mechanism in Cooperatives," Annals of Public and Cooperative Economics, vol. 72, pp. 209-228, 2001.

[40] H.S. James and M.E. Sykuta, "Farmer Trust in Producer- and InvestorOwned Firms: Evidence from Missouri Corn and Soybean Producers," Agribusiness, vol. 22, (2006), pp. 135-153.

[41] Devos, T, D Spini and S Schwartz, "Conflicts Among Human Values and Trust in Institutions," British Journal of Social Psychology, vol. 41, pp. 481-94, 2002

[42] R. Tuyishime, F. Memba and Z. Mbera, "The Effect of Deposit Mobilisation on Financial Performance of Commercial Banks in Rwanda," International Journal of Small Business and Entrepreneurship research, Vol. 3, No. 6, pp. 44-71, 2015

[43] Faidah, Siti Nur., Dewi, Retno Mustika, "Penerapan sistem Tanggung Renteng Sebagai Upaya Mewujudkan Partisipasi Aktif Anggota Dan Perkembangan Usaha di Koperasi Perempuan Setia Bhakti Jawa Timur," Jurnal online Universitas Negeri Surabaya, 2, 2013.

[44] A. Othman, F. Kari, R. Jani, and R. Hamdan, "Factors Influencing Cooperative Member-ship and Share Increment: An Application of the Logistic Regression Analysis in the Malaysian Cooperatives," World Review Of Business Research, vol. 2, no. 5, pp. 24-35, 2012.

[45] Rajesh, Agrawal, Raju K V, Reddy Prathap, Shrinivasan R ,Sriram M S, "Member-funds and Cooperative Performance?," IIMA Working Papers WP2002-10-01, Indian Institute of Management Ahmedabad, Research and Publication Department, 2002.

[46] Ahmed, Khan and Khan, Raki, "Disclosure Practices and Governance Quality : Evidence From Micro Finance Institutions," Journal of Accounting \& Organizational Change, Vol. 12, No. 3, pp. 325-350, 2016.

[47] Z. Fungáčová and L. Weill, Trusting Banks in, BOFIT Discussion Papers: 9/2017, BOFIT-Institute for Economies in Transition, Bank of Finland, 2017.

[48] Pozzobon, Daniela Maria, Decio Zylbersztajn, Member Participation in Cooperative Governance: Does Heterogeneity Matter? Encontro da ANPAD XXXV, Rio de Janeiro, September 2011, 2011. 
[49] N.W. Marwa and M.J. Aziakpono, "Financial Sustainability of Tanzanian Saving and Credit Cooperatives," International Journal of Social Economics, Vol. 42. Issue: 10, pp. 870-887, 2015.

[50] M. Spence, "Job Market Signaling," The Quarterly Journal of Economics, Vol. 87, No. 3. pp. 355-374, 1973.

[51] Ferial,F . Suhadak, S.R. Handayani, "Pengaruh Good Corporate Governance terhadap Kinerja Keuangan dan Efeknya terhadap Nilai Perusahaan (studi pada badan Usaha Milik Negara yang terdaftar di
Bursa Efek Indonesia periode 2012-2014)," Jurnal Administrasi Bisnis, Vol. 33, No. 1, 2016.

[52] M.C. Jensen and W.H. Meckling, "Theory of The Firm: Managerial Behavior, Agency Cost and Ownership Structure," Journal of Financial Economics, vol. 3, no. 4, pp. 305-360, 1976.

[53] Solimun, Fernandes.A.A.R., Nurjannah, Metode Statistika Multivariat Pemodelan Persamaan Struktural (SEM) Pendekatan WarpPLS, UB Press. Malang, 2017. 